\title{
Performing the good death: the medieval Ars moriendi and contemporary doctors
}

\author{
K Thornton, ${ }^{1}$ C B Phillips ${ }^{2}$
}

${ }^{1}$ Medical School, Australian National University, Canberra, Australia; ${ }^{2}$ Social Foundations of Medicine, Medical School Australian National University, Canberra, Australia

\section{Correspondence to:}

Christine B Phillips, Social

Foundations of Medicine,

Medical School, Australian

National University, Canberra

2602, Australia; Christine.

phillips@anu.edu.au

Received 16 March 2009

\section{ABSTRACT}

Death is inevitable, but dying well is not. Despite the role of medical professionals as overseers of dying in contemporary society, there is comparatively little discourse among doctors about the constituents of a good death. In the 15th century, by contrast, the Ars moriendi portrayed normative medieval ideas about good and bad deaths. At a time when dying could be viewed as a performed battle against damnation, the Ars moriendi codified a set of moral precepts that governed the expression of autonomy, relations between the dying and the living and orientation towards God. In these images, dying well is a moral activity that results from active decisions by the dying person to turn from earthly preoccupations to contemplation of, and submission to, the divine. It is likely in contemporary society that there is a range of understandings of the "good death". While attitudes to personal autonomy may differ, reflectiveness and dying at home in the presence of family (expressed in the Ars moriendi), remain part of many modern notions of the good death. We argue that medical institutions continue to construct death as a performed battle against physical debility, even when patients may have different views of their preferred deaths. The dialectic approach of the Ars moriendi may offer a way for contemporary doctors to reflect critically on the potential dissonance between their own approach to death and the variety of culturally valorised "good deaths".

In wealthy countries in the 21st century, questions of dying well tend not to be part of everyday discourse. Many young people have encountered death only on film or in television programmes. ${ }^{1}$ Currently around 70\% of residents of England and Wales die in hospital, ${ }^{2}$ and it is likely that the proportion is similar in Australia. ${ }^{3}$ Although doctors are often the overseers of dying in the West, studies suggest that they may misunderstand the real wishes of the dying while focusing on the physiological aspects of death. ${ }^{45}$

By contrast, in medieval Europe, death was part of the fabric of existence. It is estimated that in the late Middle Ages (generally regarded as the period from 1300 to 1500), three out of every 10 babies died in infancy. ${ }^{6}$ Against this background were famines, the Hundred Years War and plagues, all resulting in widespread death. The outbreak of the Black Death from 1347 to 1350, for example, is estimated to have killed $30-50 \%$ of Europe's population. ${ }^{7}$ One consequence of this omnipresence of death in the Middle Ages is that questions of death and dying well became everyday preoccupations, assisted by the widely disseminated book of woodcuts, the Ars moriendi (literally, the art of dying).
The medieval Ars moriendi is structured around inspirations (illustrations of the good death) and temptations (illustrations of the bad death). Leget ${ }^{8}$ has suggested that a modern Ars moriendi would include consideration of key concepts such as death and the afterlife, autonomy and self, pain control and medical intervention, attachment and relations, and guilt and life balance. These do not map exactly onto the inspiration/temptation approach of the medieval Ars moriendi, though they do represent modern preoccupations. In this paper we focus particularly on the visual dialectic used in the medieval Ars moriendi, arguing that this reflective learning method may be of contemporary use in clarifying doctors' own notions of the good death through simultaneous contemplation of the bad death. We begin by reviewing research on historical constructions of the good death. We then closely analyse a pair of images from the Ars moriendi. Finally, we discuss the implications of the structure and focus of the Ars moriendi for developing medical awareness of, and support for, contemporary cultural notions of the good death.

\section{ARS MORIENDI}

The Ars moriendi belongs to a corpus of texts in the late Middle Ages that codified the integration of Church teaching and religious reflection into everyday life. At the turn of the 15th century, papal authority had been reasserted when a dispute about the democratisation of religious texts had been settled with the banning of Wycliffe's English language Bible and a papal bull proscribing scripture not in Latin. ${ }^{9}$ At the Council of Constance in 1414-1418, the Council ordered the production of a book about how to die well. ${ }^{10}$ Two principal versions of this book have survived. The longer version entitled Tractatus artis bene moriendi (A Treatise on the Art of the Good Death) includes six sections of Latin text addressing death as an inevitable part of living, the five temptations (attachment to worldly goods, infidelity, despair, impatience and spiritual pride), questions to ask the dying man, admonitions to imitate Christ's life, advice for families on managing death, and prayers for the dying. ${ }^{10}$

The second surviving version is commonly referred to as the Ars moriendi. This version comprises five paired woodcuts, one single woodcut and some accompanying text. Each pair consists of one woodcut depicting temptation and one depicting inspiration for the dying person. The devil uses these temptations to inveigle humans into committing one of the seven deadly sins (avarice, lust, gluttony, pride, anger, envy, sloth). The use of images enabled the messages to 
be understood and accessed by members of the general populace who were illiterate. ${ }^{10}$ The Ars moriendi become an enormously popular work, read well into the 1700s. ${ }^{11}$ Its messages were adapted by the author(s) of the popular Everyman morality play, in which Death informs Everyman he is about to die, starting a process where Everyman must overcome the five temptations if he is to die well. ${ }^{12}$

\section{HISTORICAL CONSTRUCTIONS OF DYING WELL}

Cultural attitudes towards death are not historically constant. In his seminal work Hour of our death, Philippe Aries proposes five attitudes towards death adopted by people from Western countries. ${ }^{13}$ These attitudes are arranged in rough sequence, though Aries recognises they do not follow a simple linear trajectory, with several sometimes being held simultaneously. The first of these attitudes is a oneness between living and dead, in which dying was accepted as part of everyday life. With this attitude, death was tame, something that everyone must yield to almost as if they were going to sleep. ${ }^{14}$ Aries elaborates this idea with numerous examples of how death can be tame, including in the 20th century.

The second attitude articulated by Aries is the "death of the self", in which death was regarded as the enemy. People were terrified of eternal damnation and relied upon religion to help them get through the process of dying. Dying was reframed as a liturgical melodrama (using texts such as the Ars moriendi or the Everyman morality play) with a dramatic performance by the priesthood at the deathbed. Aries argues that in the Middle Ages, generally the gentry saw death as an enemy (consistent with the second attitude), while peasants still regarded death as natural (consistent with the first attitude).

Aries's third attitude is a virtual denial of death, dating from the time of the Reformation. This attitude resulted in attempts to banish the dead from the community of the living, which Aries argues still occurs today. Aries has been criticised for his limited conceptualisation of this attitude, ${ }^{15}$ which was added to his argument after he had already published his ideas focusing on the other four attitudes.

Aries's fourth attitude is one in which more attention was given to the survivors than to the decedent. This became evident in the 19th century, as the rituals of death became more sentimental, and formal mourning became a family responsibility. This attitude is still present to some extent in today's society, with emphasis placed on supporting the grieving family after a death. ${ }^{15}$ Finally, the fifth attitude described by Aries is "forbidden death", which he regards as modern society's dominant attitude. He claims that with this attitude, bureaucratisation and hospitalisation rob death of any dignity it may have had in the past.

Aries's research into death has been criticised for its Francocentrism ${ }^{16}$ and its chronology. ${ }^{17}$ For the purposes of this paper, a more pertinent critique of Aries's work is made by Roy 1 Porter, ${ }^{14}$ who observes that Aries provides an insufficient account of the medical or scientific dimensions of death until his final section, in which he tends to censure the role of medicine.

Kellehear suggests that as effective medical intervention is highly valued in today's society, its impact on the contemporary construction of the good death is inevitable, though multilayered. ${ }^{18}$ Over the past century, the dying process has been increasingly medicalised, in complex ways. While palliative care has evolved as a field of managed, naturalised death for those with evolving fatal illnesses, so too has the "high-tech" death for those whose deaths may be acute. The high-tech death, in particular, appears to be accompanied by medical anxieties about the ambiguous role of technology in end-of-life activities that may appear to be engaging in "medical futility". ${ }^{19}$

Aries does not give a simple definition of what comprises a good death in a particular era. He does, however, stipulate that as a general principle, when individuals feel that they are approaching the end of their life, it is important they prepare adequately. The historian Paul Binski also emphasises the role of preparation in a good death. ${ }^{20}$ He suggests that a good death is one that ensures satisfactory continuity with life. To ensure appropriate spiritual preparation, people in the Middle Ages needed to understand the basic principles of sin, confession and penance. Binski argues that documents such as the Ars moriendi were vital to the education of the public about dying well.

\section{GOOD AND BAD DEATH IN THE IMAGES OF THE ARS MORIENDI}

The Ars moriendi encapsulates the second attitude outlined by Aries, in which death is viewed as a performance framed by religious belief. For the viewers of the Ars moriendi, the existence of life after death was a social fact, with the text functioning as a guide to maximising chances of entering heaven and minimising the sojourn in purgatory.

To illustrate the encoded messages of the Ars moriendi, we focus in detail on two images in the Ars moriendi stored in the British Museum. ${ }^{21}$ This version is believed to have been produced around 1450, possibly in Cologne. Each image contains a banderole on which Latin admonitions or injunctions were written. The two images we describe in this section are images $5 \mathrm{a}$ and $5 \mathrm{~b}$, which show the temptation of "attachment to worldly goods" and the inspiration of "detachment" (figs1, 2).

In the woodcut depicting the temptation of attachment to worldly goods, the dying man lies in bed. Three demons crowd around him, pointing to his massive house and his loved ones.

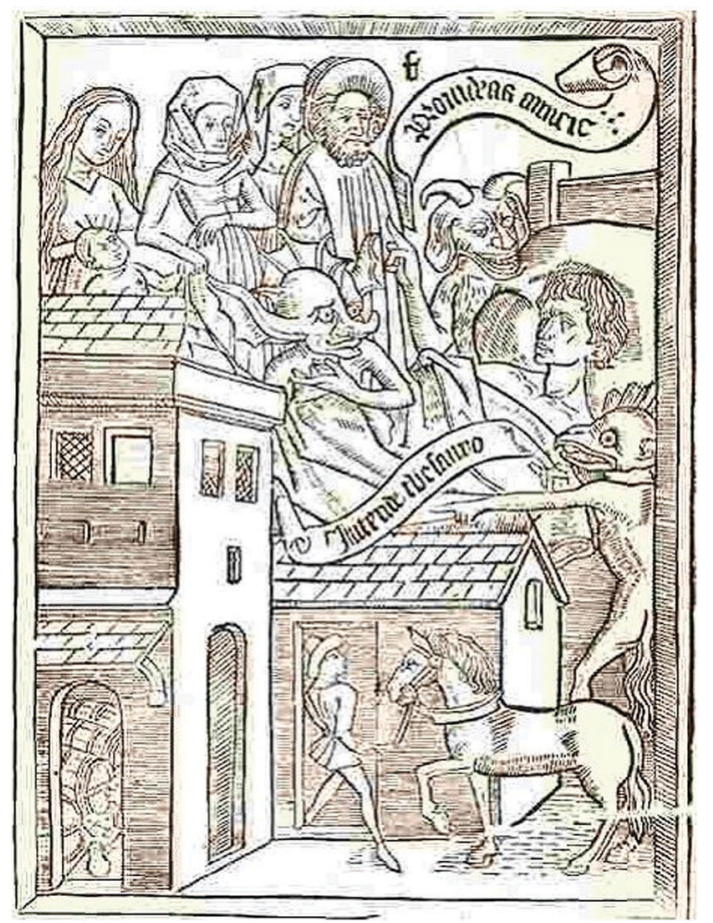

Figure 1 The Temptation of Attachment to Worldly Goods. Ars moriendi, Image 5a, The Ars moriendi (Editio princeps, circa 1450). A reproduction of the copy in the British Museum, 1881. Reproduction sourced from http://userpage.fu-beilin.de/ aeimhof/seelefr.htm (accessed 9 Mar 2009). 


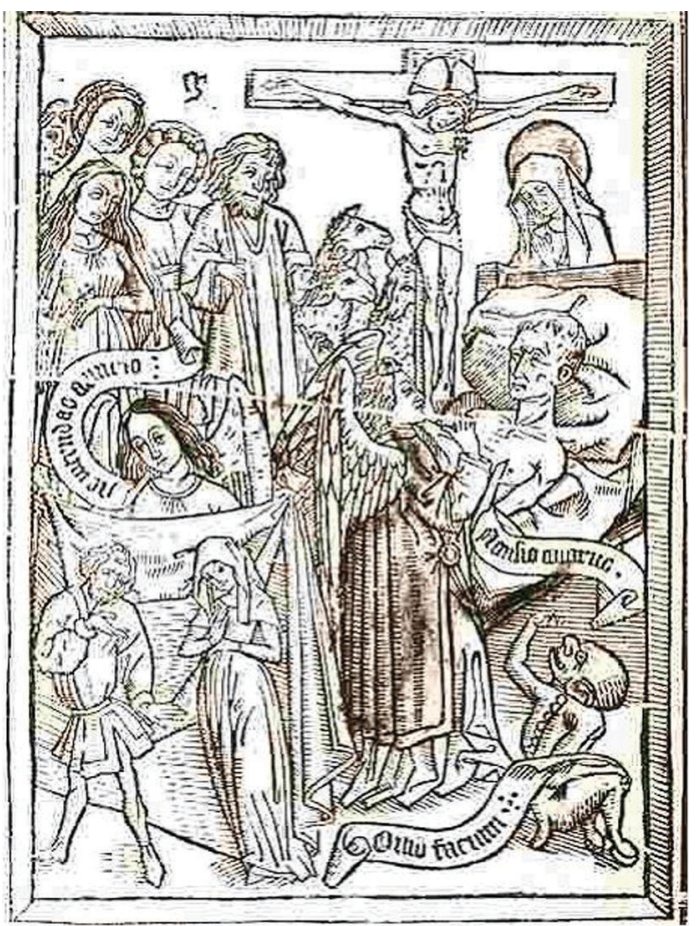

Figure 2 The Inspiration of Detachment. Ars moriendi, Image 5b, The Ars moriendi (Editio princeps, circa 1450). A reproduction of the copy in the British Museum, 1881. Reproduction sourced from http://userpage. fu-berlin.de/ aeimhof/seelefr.htm (accessed 9 Mar 2009).

The demons are attempting to distract him from thoughts of heaven by reminding him of the worldly enjoyment that he is leaving behind. The banderoles in this image tempt the man to provide for his friends ("provideas amicis") and to look after his possessions ("intende thesauro").

The representation of the opulent house occupies close to a half of the artwork, emphasising to viewers of the Ars moriendi its importance to the man. The house includes a cellar with a servant and four casks of wine. Vines, vineyards, grapes and wine are frequently used in Christian iconography as symbols of prosperity. ${ }^{22}$ The steed and the groom depicted in this woodcut are further evidence of the man's richness of material possessions. Akerboom suggests that the servant may be stealing the wine, underscoring the folly of putting one's faith in material possessions. ${ }^{23}$ This bad death, the image asserts, arises from a series of bad choices made throughout life, through the accumulation of property and distractions; at the deathbed, the person's poor choices throughout life are forcibly presented to him by the demons.

In this artwork, the family (and possibly friends) of this man are depicted as distractions for the man in his final hour. The work implies that the man's attachment to people makes it more difficult for him to enter heaven. These loved ones may want money left to them after his death, rather than to the Church, a temptation that is alluded to in the banderole advising the man to provide for his friends.

The second artwork in the pair depicts the inspiration of detachment. The dying man lies in his bed with the Virgin Mary and Christ on the cross pictured near the head of the bed. A shepherd, four sheep and four people are also pictured in the left upper corner of the artwork. A demon crouches in the lower right corner, overpowered by two angels. In this artwork, the text in the banderoles instructs readers that they should not be greedy ("non sis auarus"), and that they should not concern themselves for their friends ("ne intendas amicis").

The words "Quid faciam" are found on the banderoles of the second image. "Quid faciam" is a reference to Paul's request to Christ "Quid faciam, Domine?" ("Lord, what do you want me to do?") after his transcendent moment on the road to Damascus. These words would have been readily recognisable to medieval readers of the Ars moriendi. The reader would have understood that Paul's conversion moment was a profound, unexpected and unsought disruption of his life. The only response possible for Paul was submission to the Divine. The inclusion of this shorthand verse signals the need for submission and acceptance in the face of the inexplicable-in this case, death.

Featured in a prominent position at the top of the woodcut is a portrayal of Christ on the cross. The crucifixion of Christ is one of the most frequently represented subjects in medieval art, ${ }^{22}$ here representing Christ's sacrifice and also the involvement of God in the lives of men, including at a man's deathbed.

The Virgin Mary is depicted as a tender mother-figure standing at the head of the bed. There are two angels in this image. Angels are intermediaries between God and humans and tend to feature prominently in medieval art. ${ }^{22}$ The angel nearest the bed is depicted lifting a finger in admonition, echoing the words of the banderole instructing the man not to be greedy.

The other angel holds a sheet to conceal a man and a woman in the bottom left corner. There are a number of explanations for this, exemplifying the ambiguity of the artwork when viewed today. The man and woman being concealed may be the dying man's wife and physician (now redundant ${ }^{24}$ or his loved ones, being shielded so the dying man is not distracted from thoughts of heaven.

The images discussed here represent a contrast in two moral views of detachment and engagement in the process of dying. Detachment is presented as the more exalted way of dying, with attachment and avarice not considered part of the good death. Even though many people are present at the deathbed, the viewer is encouraged to contemplate the religious imagery and focus on the transcendent moment of union with God and detachment from earth. This short summary of images is necessarily limited, as it addresses only one of the five pairs in detail; however, in reviewing all the images, the same themes of detachment and submission to the Divine recurred.

\section{CAN THERE BE A CONTEMPORARY ARS MORIENDI?}

Contemporary society differs significantly from the society of the viewers of the Ars moriendi. Secularisation, individualism and the speed of the dying process are all factors that can determine a range of "cultural scripts" for the good death. ${ }^{25} 26$ Approximately $15 \%$ of Australians ${ }^{27}$ and residents of England and Wales ${ }^{28}$ claim to be of no religion, and are unlikely to emphasise the immanence of the afterlife when constructing their notion of the good death. Individual autonomy was not central to the good death for readers of the Ars moriendi (indeed, for the temptations to be effective, the medieval man would have to exercise individual will in defiance of God). As has been demonstrated in the contemporary euthanasia debate, autonomy and control over one's destiny are, for some, integral to the good death. ${ }^{29}$

Despite this variation, the perceptions of dying and death in a Western country do have some common elements. One popular understanding of the good death in the 21st century is one in which a person dies at home surrounded by family and their community at the end of a long and fulfilled life. ${ }^{25}$ Far from 
detaching from family and friends, the good death is often one in which the person remains connected to family through the time of dying. ${ }^{8}$

It may be argued that there is no need for doctors to reflect upon on their own views of the good death, provided they understand and respect the patients' views of the good death. But the world of medicine is such a powerful, "common-sense" world that unless doctors consciously explore the idea of dying well, they may unconsciously prioritise their profession's valorised approaches. The research into the medical disconnection between patients' views of good deaths and the medical view of the good death does not indicate that doctors are innately poor at understanding patient's beliefs. Rather, doctors have been trained to prioritise a biomedical view of dying, in which "fighting back" at death, rather than acceptance, may be valorised by professionals. ${ }^{30}$ Thirty years ago, Susan Sontag pointed out the martial metaphors used by doctors to characterise the behaviour and appropriate medical response to cancer. ${ }^{31}$ Just as the medieval view of the good and bad death encapsulated decisions made throughout a lifetime, so the current death may represent a series of decisions made about medical care throughout the person's illness, many of which occur before the person enters palliation.

Throughout medical training, death is primarily defined as a physiologic event-a framework that is often reinforced by medical experience. ${ }^{30}{ }^{32}$ When death is located in a medical institution, medical professionals (with the exception of palliative care professionals) often approach death as a performed battle against debility and physical decline. ${ }^{19}$ In this way, doctors mirror the role of the clergy in Aries's second attitude, who adopted a battle against death while the common man often preferred the more "natural" death.

The Ars moriendi refers us back to another time, when death was performative and submission to divine will a key determinant of the good death. Aries's view of contemporary death as forbidden may have relevance for the ways medical professionals approach death. The Ars moriendi structures its statements around simple dialectical reasoning: if a bad death can be recognised, so should its opposite, the good death. In teaching, we have found that the structure of the Ars moriendi is useful as a tool for reflecting on valued attitudes towards death. Students are encouraged to visualise the bad death and then describe its opposite, using the same structure as the original Ars moriendi. The focus of the medieval Ars moriendi, with its strong belief in the afterlife and in submission to the will of God, functions as a "defamiliarising" tool, which enables students to look at something apparently familiar (how we think we want to die) in a new way. Describing good and bad deaths visually are productive ways of clarifying the medical profession's attitude(s) to the good death. We suggest that employing an artist in a workshop for students and doctors to elaborate good and bad deaths might encourage profound reflection. The resultant artworks could be given to doctors as their own objects of contemplation, again borrowing from the Ars moriendi tradition.

Medieval clerics may have used the Ars moriendi as a way of promulgating an agreed notion of the good death. Contemporary medical professionals are differently placed. They work in a society where notions of the good death are numerous and complex, and they must respond respectfully to these notions. In order to do this, they need to understand their own notions of the good death. The strategies and focus of the Ars moriendi may be usefully updated to clarify for doctors their own attitudes to good and bad deaths.

Acknowledgements: We are grateful to the staff of the National Library of Australia, to Dimity Phillips for advice on iconography in medieval art and to Ruth Phillips for translation of documents from German.

Competing interests: None declared.

Provenance and peer review: Not commissioned; externally peer reviewed.

\section{REFERENCES}

1. Durkin KF. Death, dying and the dead in popular culture. In: Bryant CD, ed. Handbook of death and dying. London: Sage, 2003.

2. Office for National Statistics. Mortality statistics: deaths registered in 2007. Series DRO7. London: ONS, 2008. http://www.statistics.gov.uk/downloads/theme health/ DR2007/DR 07 2007.pdf (accessed 13 Mar 2009).

3. McNamara B, Rosenwax L. Factors affecting place of death in Western Australia. Health Place 2007;13:356-67.

4. Steinhauser KE, Clipp EC, McNeilly M, et al. In search of a good death: observations of patients, families and providers. Ann Intern Med 2000;132:825-32.

5. Kaufman SR. Intensive care, old age, and the problem of death in America. Geronologist 1998;38:715-25.

6. Youngs D. The life-cycle in Western Europe, c.1300-c.1500. Manchester Manchester University Press, 2006.

7. Gottfried RS. The Black Death: natural and human disaster in medieval Europe. New York: Free Press, 1983.

8. Leget C. Retrieving the ars moriendi tradition. Med Health Care Philos 2007;10:313-9.

9. Levy IC, ed. A companion to John Wyclif, late medieval theologian. Brill's Companions to the Christian Tradition 4. Leiden: Brill, 2006.

10. O'Connor MC. The art of dying well: the development of the Ars moriendi. New York: AMS Press, New York, 1966

11. Wakefield GS. The Westminster dictionary of Christian spirituality. Louisville, KY Westminster John Knox Press, 1983.

12. Gilman D. Everyman and company: essays on the theme and structure of the European moral play. New York: AMS Press, 1989.

13. Aries P. The hour of our death. Weaver H, trans. New York: Oxford University Press 1981.

14. Porter R. The hour of Philippe Aries. Mortality 1999;4:83-90.

15. Australian Centre for Grief and Bereavement. Bereavement counseling and support service, 2008. (Updated 3 Feb 2009.) http://www.grief.org.au/couns.html (accessed 9 Mar 2009)

16. Mitchell A. Philippe Aries and the French way of death. Fr Hist Stud 1978;10:684-95

17. Stone L. Death and its history. New York Review of Books 12 October 1978:22-32

18. Kellehear A. A social history of dying. New York: Cambridge University Press, 2007

19. DelVecchio Good MJ, Gadmer NM, Ruopp P, et al. Narrative nuances on good and bad deaths: internists' tales from high-technology work places. Soc Sci Med 2004;58:939-53.

20. Binski P. Medieval death: ritual and representation. New York: Cornell University Press, 1996.

21. Rylands WH, ed. The Ars moriendi. (Editio princeps, circa 1450). A reproduction of the copy in the British Museum. London: Wyman and Sons, 1881.

22. Ross L. Medieval art: a topical dictionary. Westport: Greenwood Press, 1996.

23. Akerboom D. Continuity and discontinuity between the late medieval Ars moriendi and Luther's sermon von der Bereitung zum Sterben. In: Blommestijn H, Caspers C, Hofman R, eds. Spirituality renewed: studies on significant representatives of the modern devotion. Leuven: Peeters, 2003.

24. Bullen G. Introduction. In: Rylands WH, ed. The Ars moriendi (Editio princeps, circa 1450). A reproduction of the copy in the British Museum. London: Wyman and Sons, 1881.

25. Seale C, van der Geest S. Good and bad death: introduction. Soc Sci Med 2004:58:883-5

26. Walter T. Historical and cultural variants on the good death. BMJ 2003;327:218-20.

27. Australian Bureau of Statistics. Census of population and housing, 2001. http:// www.abs.gov.au/Ausstats (accessed 10 Aug 2008)

28. Office for National Statistics. Census 2001: ethnicity and religion in England and Wales. (Updated 2003.) http://www.statistics.gov.uk/census2001/profiles/ commentaries/ethnicity.asp\#religion (accessed 13 Mar 2009).

29. Schmidt U. Euthanasia, autonomy and beneficence. Nordic Journal of Theology 2002; 56:132-51.

30. Low JT, Payne S. The good and bad death perceptions of health professionals working in palliative care. Eur J Cancer Care 1996;5:237-41.

31. Sontag S. Illness as metaphor. New York: Farrar, Strauss and Giroux, 1978

32. Atwood-Gailey E. Write to death: news framing of the right to die conflict, from Quinlan's coma to Kevorkian's conviction. Westport: Greenwood Publishing Group, 2003. 